\title{
Adjustments Needed for the Use of Nutri-Score in the Netherlands: Lack of Selectivity and Conformity with Dutch Dietary Guidelines in Four Product Groups
}

\author{
Charlotte van Tongeren ${ }^{1,2}$, Léon Jansen ${ }^{2, *}$ \\ ${ }^{1}$ Department of Human Nutrition, Wageningen University \& Research, Wageningen, The Netherlands \\ ${ }^{2}$ Schuttelaar \& Partners, Wageningen, The Netherlands
}

Email address:

charlottevantongeren@gmail.com (C. van Tongeren), leon.jansen@schuttelaar.nl (L. Jansen)

${ }^{*}$ Corresponding author

To cite this article:

Charlotte van Tongeren, Léon Jansen. Adjustments Needed for the Use of Nutri-Score in the Netherlands: Lack of Selectivity and Conformity with Dutch Dietary Guidelines in Four Product Groups. International Journal of Nutrition and Food Sciences.

Vol. 9, No. 2, 2020, pp. 33-42. doi: 10.11648/j.ijnfs.20200902.11

Received: February 28, 2020; Accepted: March 17, 2020; Published: April 13, 2020

\begin{abstract}
Objective: The study investigates the applicability of Nutri-Score in the Netherlands, by comparing Nutri-Score with Dutch Choices criteria and Dutch dietary guidelines in different product groups. Design: For products within the product groups Cheese, Ready meals, Soups and Meal sauces, nutritional data from three large national retailers was collected and the products' corresponding Nutri-Scores were calculated. The distribution of the products among the different Nutri-Scores (A-E) per product group was calculated. To determine whether the healthiness of products correspond to a healthy score (A/B) and unhealthy products correspond to an unhealthy score (D/E), all product scores were compared to product group-specific criteria of the Dutch Choices Foundation. Furthermore, to identify whether there was a correlation between Nutri-Score and one or more nutrient(s), single and multiple regression analyses were performed. Finally, the Nutri-Score of products was compared with Dutch dietary guidelines. Data characteristics: 2299 products were included in this study, of which 1396 cheeses, 343 ready meals, 370 soups and 190 meal sauces. Results and conclusions: The current study shows that for the product groups Cheese, Ready meals, Soups and Meal sauces, there is an uneven distribution of the products among the different Nutri-Scores, Nutri-Scores of a great amount of products are not in line with Dutch Choices criteria and - dietary guidelines and there is no high correlation between Nutri-Score and health influencing nutrients in most product groups. Now that the Dutch Government has decided to implement Nutri-Score as the new FOP-label, it is advised to look into the possibilities to adapt the algorithm behind the score to a product group-specific algorithm based on Dutch guidelines.
\end{abstract}

Keywords: Nutri-Score, Dutch Choices Criteria, Dietary Guidelines, Product Data Study

\section{Introduction}

Improving public health policies through a multifactorial effort is essential to the worldwide prevention and control of diet-related non-communicable diseases (NCDs) [1]. The World Health Organisation (WHO) has been emphasizing on the crucial role of the Government for achieving lasting change in public health and encouraged governments to build on their existing structures and processes that already address aspects of nutrition, physical activity and diet [2].

Accordingly, in 2014 the Dutch Government together with 70 other parties reached an agreement on improving Dutch public health, known as the National Prevention Agreement (Nationaal Preventie Akkoord, NPA) [3]. One of the parties' ambitions is to significantly reduce rates of obesity and overweight in youngsters and adults by 2040 . To reach this ambition, several ambitious goals were formulated, starting by creating an overall healthier food environment for Dutch society [3]. Consuming a variety of products from the Wheel of Five (Schijf van Vijf, Sv5) - a visual representation of the Dutch dietary guidelines including five food groups - underlie a healthy food pattern [4]. Eating vegetables, fruits, dairy and whole grain products, and drinking enough water make up an important part of this pattern [5]. Products high in sodium, 
sugar and saturated fatty acids (SAFA) or low in fibres do not fall within the Sv5 and are considered as less healthy [6, 7].

From 2006 until 2016 the Dutch Choices label (also called "Ik Kies Bewust-logo" or "het Vinkje") was displayed on many different food products to guide consumers in choosing the healthy option within a product group [8]. The Choices Label selects the best-in-class products based on product group-specific criteria [9]. However, in 2016 the Ministry of Health, Wellbeing and Sports (VWS) decided to no longer support this label as being the national front-of-pack (FOP) nutrition label, resulting in the termination of the label in October 2018 [10]. To continue to facilitate consumers in making healthy food choices, VWS decided to introduce a new FOP nutrition label by 2020 at the latest. Accordingly, the Sv5 criteria must be included in the development of a new FOPlabel, as they are based on the Dutch dietary guidelines. Moreover, independent consumer research has to be taken into account, as understandability to the consumer is key [3].

One of the labels that has been in the running to become the new national FOP-label is the from France originating NutriScore (Figure 1) [11, 12]. The Nutri-Score is a 5 colour nutrition labelling which is meant to orient consumers towards healthier food choices at the point of purchase and as an incentive for food manufacturers to reformulate their products towards healthier compositions [13]. The label consists of five boxes with colours ranging from dark green to dark orange, and letters that grade foods according to their overall nutritional quality; A for foods with the 'best' nutritional quality to $\mathrm{E}$ for foods with the 'worst' nutritional quality [11]. The Nutri-Score is derived from the UK's Food Standards Agency nutrient profiling system (FSA-NPS) and is calculated by using the nutrient content per 100 grams or 100 millilitres for food and beverages. The score is foremost based on the French dietary guidelines, that allocates negative points for fruit, vegetables, nuts, fibres and protein content, and positive points for energy, sugar, SAFA and sodium content [12].
Following public health authorities in France, Belgium, Spain, Germany and Switzerland, VWS is planning to implement the Nutri-Score in 2021, provided that the score is in line with the Dutch dietary guidelines $[14,15,16]$.

The current study is aimed at investigating the applicability of Nutri-Score in the Netherlands, by comparing Nutri-Score with Dutch Choices criteria and Dutch dietary guidelines in different product groups. In this study, Nutri-Score is considered a proper FOP-label if the scored-products are in line with these guidelines and criteria. The findings will indicate to what extent Nutri-Score really orients consumers towards the healthy food choice within a product group.

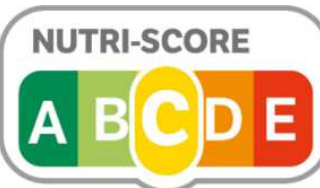

Figure 1. The Nutri-Score.

\section{Methods}

\subsection{Selection of Product Groups}

In this study, four different product groups were studied, namely Cheese, Ready meals, Soups and Meal sauces. Table 1 provides an overview of Dutch consumption-, nutritional - and Dutch Choices product criteria data for all four product groups. Both basic and non-basic food products were analysed to represent both groups of food products. Basic food products are products that substantially contribute to the intake of essential nutrients, such as vegetables, carbohydrate-sources, meat, dairy, water, oils, and combined meals. Soups, sauces, snacks, beverages, juices and spreads belong to the non-basic food products, that are regarded as products that do not substantially contribute to the intake of essential nutrients [8].

Table 1. Dutch consumption-, nutritional-and product criteria data for the product groups Cheese, Ready meals, Soups and Meal sauces.

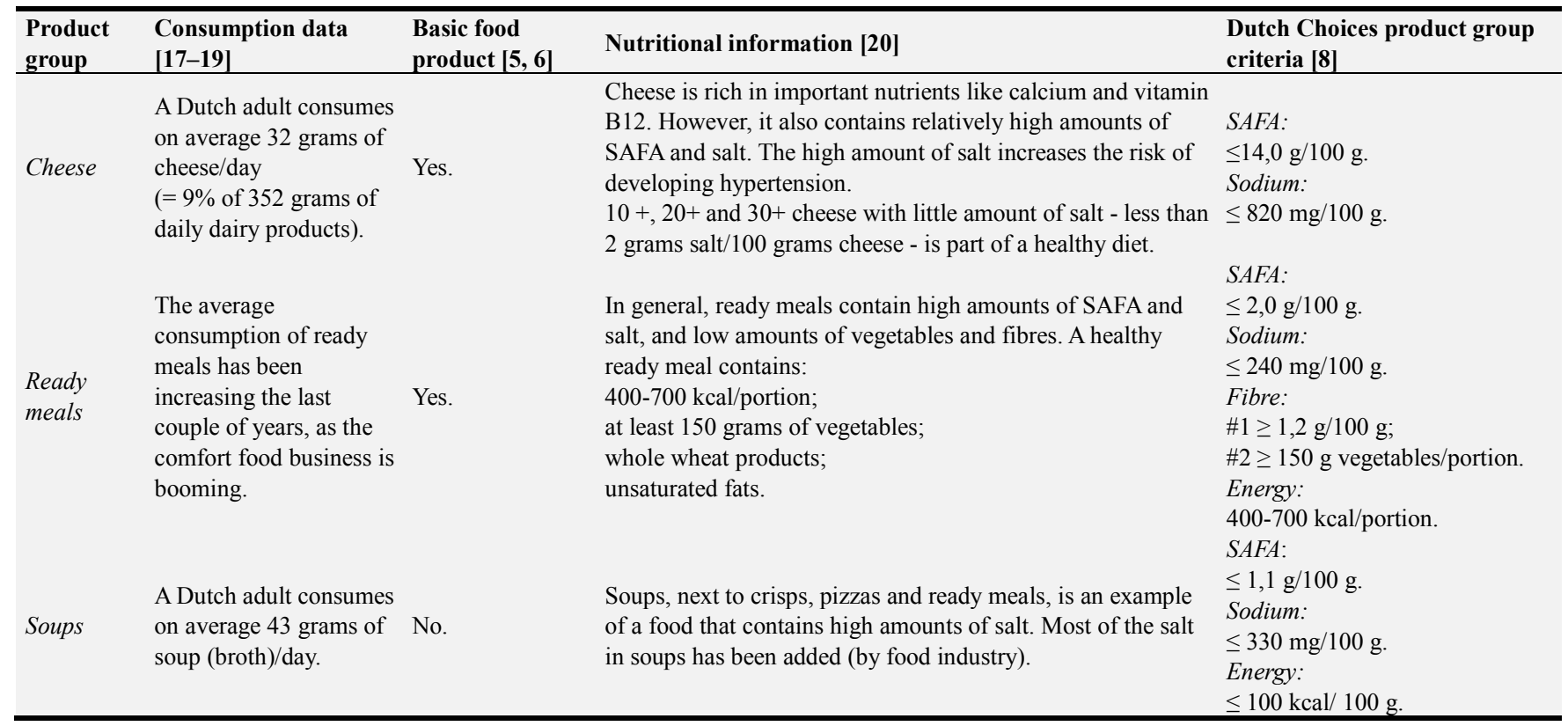




\begin{tabular}{|c|c|c|c|c|}
\hline $\begin{array}{l}\text { Product } \\
\text { group }\end{array}$ & $\begin{array}{l}\text { Consumption data } \\
{[17-19]}\end{array}$ & $\begin{array}{l}\text { Basic food } \\
\text { product }[5,6]\end{array}$ & Nutritional information [20] & $\begin{array}{l}\text { Dutch Choices product group } \\
\text { criteria [8] }\end{array}$ \\
\hline $\begin{array}{l}\text { Meal } \\
\text { sauces }\end{array}$ & $\begin{array}{l}\text { A Dutch adult consumes } \\
\text { on average } 35 \text { grams of } \\
\text { sauce/day. }\end{array}$ & No. & $\begin{array}{l}\text { Sauces contain high amounts of salt and sugar. The amount } \\
\text { of salt that we ingest is mostly determined by the frequency } \\
\text { and amount of consumption of this product. }\end{array}$ & $\begin{array}{l}\text { SAFA: } \\
\leq 1,1 \mathrm{~g} / 100 \mathrm{~g} \\
\text { Sodium: } \\
\leq 450 \mathrm{mg} / 100 \mathrm{~g} \\
\text { Energy: } \\
\leq 100 \mathrm{kcal} / 100 \mathrm{~g}\end{array}$ \\
\hline
\end{tabular}

\subsection{Data Collection}

Nutritional data of products from three large national retailers Albert Heijn, Jumbo and Hoogvliet were collected, to ensure a representative and large product sample size for the Netherlands. By nutritional data is meant a table with nutritional values and a list of ingredients. Most recent nutritional data for products within the product groups Cheese and Ready meals was either provided by the retailer organisations themselves, or by the extraction of online data from their websites. The product group Cheese included all cheeses and cheese-products and the product group Ready meals included (steam) ready meals, pizzas, meal salads, quiches, pasta salads and frozen meals [8].

Hoogvliet provided datasets with nutritional values of their products within the product groups Cheese and Ready meals. These datasets were then supplemented with total percentages of fruit, vegetables and legumes (FVL), that were extracted from the products' corresponding ingredient lists found on Hoogvliet's online web shop.

Nutritional product data within product groups Cheese and Ready meals from Albert Heijn and Jumbo was extracted by means of scraping. This refers to the extraction of product information from Questionmark, an online database containing information of supermarket products on offer in Dutch supermarkets, through an application programming interface (API).

Nutritional product data for the product groups Soups and Meal sauces was collected by in shop data collection in three supermarkets in 2018. The product group Soups included all soups and broths and the product group Meal sauces included pasta sauces, vegetable- and meat sauces and gravy. To verify whether the 2018 nutritional datasets on Soups and Meal sauces was still up to date, several product samples from these datasets were compared to their corresponding products presented on the retailers' websites. Products that had been reformulated since November 2018 were adjusted in the datasets to recent formulations. In case products had been removed from any of the retailers' product range, corresponding products were deleted from the dataset.

Missing data for products in all product groups on either nutritional value and/or ingredients, was supplemented with information found on the retailer's website in question and/or on the product's brand website. Missing data for products in all product groups on portion size, was supplemented with information found on the Portie-online website from VWS [21]. Products that did not fall within a product group subcategory were also removed.

\subsection{Data Analysis}

After data collection, product duplicates and triplicates were identified and removed. Products with identical nutritional content, but different in portion size and/or presentation (Stock Keeping Unit, SKU) were not regarded as product duplicates and thereby not removed, since these products make up part of the total product range.

After data sorting, the products' corresponding Nutri-Scores were calculated. All Nutri-Scores were calculated according to the Detailed Computation of the Nutri-Score/5-Colour Nutrition Label-scheme and Veelgestelde vragen over NutriScore: Wetenschappelijk en Technisch [12, 22]. The following was calculated for all products: points per nutrient (ppn), points group A, points group C and final scores. Group A included the sum of points for unhealthy nutrients energy, sugar, SAFA and sodium, and group C included the sum of points for healthy nutrients FVL, fibre and protein. The final scores were paired with the corresponding letter and colour. After score computation, products were filtered from dark green highest quality (lowest score) to dark orange lowest quality (highest score). In case of a product lacking nutritional information for the score's computation, the product was removed from the dataset. An exception was made for the product group Cheese, since cheese is a low-fibre food product and its nutrition label does normally not state dietary fibre.

\subsection{Applicability of Nutri-Score}

The applicability of Nutri-Score was investigated through the following three aspects:

The distribution of Nutri-Score among the different product groups;

The distribution of scored products that are (not) in line with the Dutch Choices criteria;

The correlation between Nutri-Score and health influencing nutrients.

To visualize and analyse the distribution of Nutri-Score among the different product groups, pie charts with the proportion of the different scores (A-E) per product group were created.

To determine whether healthy products correspond to a healthy score $(\mathrm{A} / \mathrm{B})$ and unhealthy products correspond to an unhealthy score $(\mathrm{D} / \mathrm{E})$, all product scores were compared to product group-specific criteria as formulated by Dutch Choices Foundation (Table 1). If a product met all the criteria within its product group, it was considered a healthy choice [8]. For every product group, the total amount and percentage of products per score-category (A-E) meeting a specific 
criterium, and meeting all criteria, was calculated. For comparing all product scores to product group-specific criteria, some additional calculations had to be made. This meant that for the product group Ready meals, the amount of energy (kcal) per portion and the amount of vegetables $(\mathrm{g})$ per portion were calculated. Moreover, to determine to what extent products contribute to the reference daily intake of a certain nutrient $^{\mathrm{a}}$, and thereby are in line with the Dutch Dietary guidelines, the percentage of a nutrient of the recommended daily allowance (RDA) or of the acceptable daily intake (ADI) was calculated. For Ready meals and Cheese, the percentage salt of the ADI was calculated. For Soups and Meal sauces, the percentage salt of the ADI and the percentage fibre of the RDA were calculated [4, 23, 24].

To identify whether there was a correlation between NutriScore and one or more health influencing nutrient(s), single and multiple regression analyses were performed with the Data Analysis Toolpak for all product groups (Microsoft Excel 2019). Spearman's correlation coefficient $r$ or R (in case of $>2$ variables), the $p$-value and the type of correlation (none-very high and positive vs. negative) were determined.

\section{Results}

\subsection{Data Characteristics}

At the start of this study, 2737 products were collected. 438 products were excluded from the dataset, because of several different reasons as shown in Figure 2. In the end, 2299 products were included in the final data analysis, of which 1396 cheeses, 343 ready meals, 370 soups and 190 meal sauces.

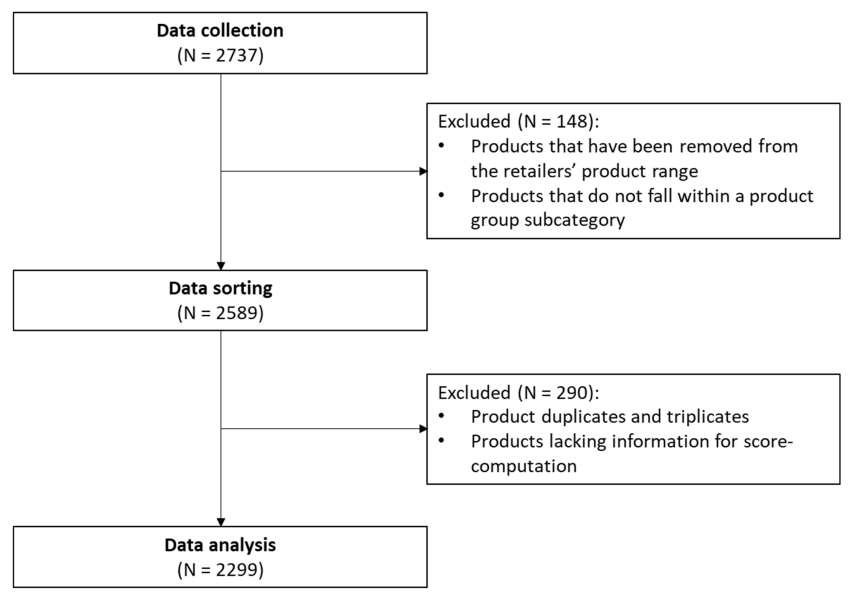

Figure 2. Data flow diagram including product data collection, - sorting and - analysis. At the start of the study, products were collected from three large national retailers $(N=2737) .148$ products were excluded, because they were either removed from the retailers' product range or did not fall within one of the product groups subcategories. After data collection, the data was properly sorted $(N=2589)$. During the data sorting process another 290 products were excluded, because they were duplicates or triplicates, or lacked information for score-computation. In the end, a total of 2299 products were included in the final data analysis. $N$, number of products.

a Reference intakes of as defined by the Dutch Health Council (Gezondheidsraad), Dutch Nutrition Centre (Voedingscentrum) and Dutch Choices Foundation (Stichting Ik Kies Bewust).

\subsection{Distribution of Nutri-Score Among the Product Groups}

The distribution of Nutri-Score among the product groups Cheese, Ready meals, Soups and Meal sauces is shown in Figures 3-6. Among Cheese $(\mathrm{N}=1396)$, products scored low in sugar, FVL and fibre (avg. ppn $0 / 10,0 / 5$ and $0 / 5$ resp.), and protein content stayed largely constant (avg. ppn A: 5/5E: 5/5). Among Ready meals $(\mathrm{N}=343)$, products scored low in sugar (avg. ppn 0/10), and high in protein (avg. ppn 4/5). Among Soups $(\mathrm{N}=370)$, products scored low in sugar and SAFA (avg. ppn both 0/10), and sodium content stayed largely constant (avg. ppn A: 3/5-C: 3/5). And among Meal sauces $(\mathrm{N}=190)$, products scored low in sugar, fibre and protein (avg. ppn 0/10,0/5 and 1/5 resp.).

As can be concluded from Figures 3-6, scores ranged from A-E in the product group Cheese and Ready meals, from A-C in the product group Soups and from A-D in the product group Meal sauces. Figures 3, 5 and 6 also show an uneven distribution of Nutri-Score among the product groups.

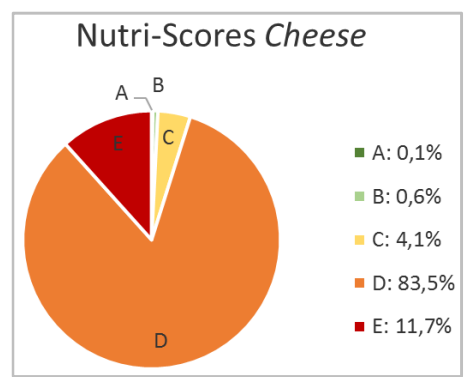

Figure 3. Distribution of Nutri-Score (\%) among the product group Cheese $(N=1396)$. Colours represent different Nutri-Scores, from A: dark green to E: dark orange. $N$, number of products.

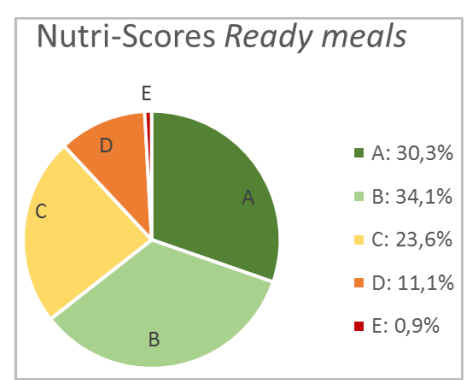

Figure 4. Distribution of Nutri-Score (\%) among the product group Ready meals $(N=343)$. Colours represent different Nutri-Scores, from A: dark green to $E$ : dark orange. $N$, number of products.

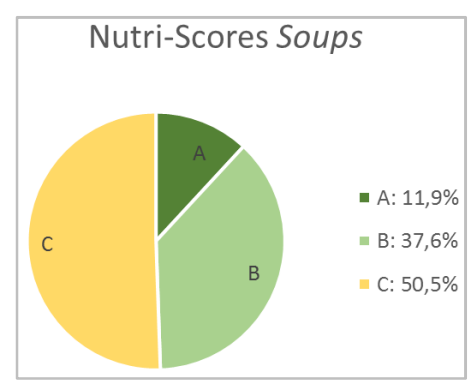

Figure 5. Distribution of Nutri-Score (\%) among the product group Soups $(N=370)$. Colours represent different Nutri-Scores, from A: dark green to $C$ : yellow. $N$, number of products. 


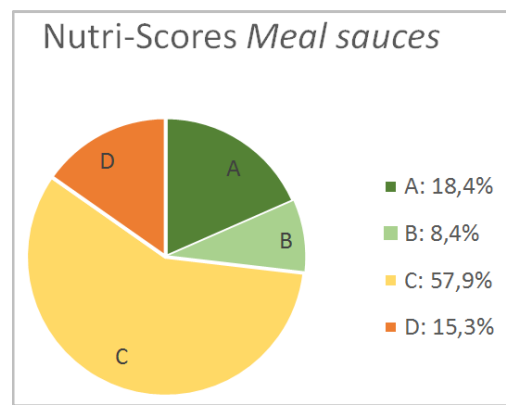

Figure 6. Distribution of Nutri-Score (\%) among the product group Meal sauces $(N=190)$. Colours represent different Nutri-Scores, from A: dark green to D: light orange. $N$, number of products.

\subsection{Compliance Nutri-Score with Dutch Choices Criteria and - Dietary Guidelines}

Results of the percentage of products per score-category (AE) meeting a product group-specific criterium, and meeting all criteria, are shown in Table 2. Only among the product group Cheese, all healthy scores corresponded to a healthy product, because these products met all criteria (A/B: 100\%). Among the product group Ready meals, however, most of the healthy scores did not correspond to a healthy product, because only a small amount of these products met all criteria (A: $21 \%$, B: $3 \%$ ). Also, for the product groups of Soups and Meal sauces not all A and B category products fulfilled all Choices criteria.

Table 2. Percentage (\%) of products per score-category (A-E) meeting a product group-specific criterium.

\begin{tabular}{|c|c|c|c|c|c|c|c|c|c|c|c|c|}
\hline & \multicolumn{2}{|c|}{ Sodium } & \multicolumn{2}{|c|}{ SAFA } & \multicolumn{2}{|c|}{ Energy } & \multicolumn{4}{|c|}{ Fibre } & \multicolumn{2}{|c|}{ All criteria } \\
\hline \multirow{6}{*}{$\begin{array}{l}\text { Cheese } \\
(\mathrm{N}=1396)\end{array}$} & $\begin{array}{l}\mathrm{Soc} \\
\mathrm{mg}\end{array}$ & & \multicolumn{2}{|c|}{$\mathrm{SAFA} \leq 14,0 \mathrm{~g} / 100 \mathrm{~g}$} & & & & & & & \multicolumn{2}{|c|}{ Sodium \& SAFA } \\
\hline & A & 100 & A & 100 & & & & & & & A & 100 \\
\hline & B & 100 & $\mathrm{~B}$ & 100 & & & & & & & $\mathrm{~B}$ & 100 \\
\hline & $\mathrm{C}$ & 93 & $\mathrm{C}$ & 85 & & & & & & & $\mathrm{C}$ & 79 \\
\hline & $\mathrm{D}$ & 86 & $\mathrm{D}$ & 21 & & & & & & & $\mathrm{D}$ & 17 \\
\hline & $\mathrm{E}$ & 23 & $\mathrm{E}$ & 3 & & & & & & & $\mathrm{E}$ & 0 \\
\hline \multirow{6}{*}{$\begin{array}{l}\text { Ready } \\
\text { meals } \\
(\mathrm{N}=343)\end{array}$} & \multicolumn{2}{|c|}{$\begin{array}{l}\text { Sodium } \leq 240 \\
\mathrm{mg} / 100 \mathrm{~g}\end{array}$} & \multicolumn{2}{|c|}{$\mathrm{SAFA} \leq 2,0 \mathrm{~g} / 100 \mathrm{~g}$} & \multicolumn{2}{|c|}{$\begin{array}{l}\text { Energy }=400-700 \\
\text { kcal }^{*}\end{array}$} & \multicolumn{2}{|c|}{$\begin{array}{l}\text { Fibre } \geq 1,2 \\
\mathrm{~g} / 100 \mathrm{~g}\end{array}$} & \multicolumn{2}{|c|}{$\begin{array}{l}\text { Fibre } \geq 150 \mathrm{~g} \\
\text { vegetables* }\end{array}$} & \multicolumn{2}{|c|}{$\begin{array}{l}\text { Sodium, SAFA, Energy, } \\
\text { Fibre \#1 \& Fibre \#2 }\end{array}$} \\
\hline & A & 63 & A & 90 & A & 82 & A & 80 & A & 64 & A & 21 \\
\hline & B & 20 & $\mathrm{~B}$ & 54 & B & 58 & B & 62 & B & 23 & $\mathrm{~B}$ & 3 \\
\hline & $\mathrm{C}$ & 4 & $\mathrm{C}$ & 21 & $\mathrm{C}$ & 28 & $\mathrm{C}$ & 35 & $\mathrm{C}$ & 7 & $\mathrm{C}$ & 0 \\
\hline & $\mathrm{D}$ & 0 & $\mathrm{D}$ & 0 & $\mathrm{D}$ & 13 & D & 11 & D & 0 & $\mathrm{D}$ & 0 \\
\hline & $\mathrm{E}$ & 0 & $\mathrm{E}$ & 0 & $\mathrm{E}$ & 0 & $\mathrm{E}$ & 33 & $\mathrm{E}$ & 0 & $\mathrm{E}$ & 0 \\
\hline \multirow{4}{*}{$\begin{array}{l}\text { Soups } \\
(\mathrm{N}=370)\end{array}$} & \multicolumn{2}{|c|}{$\begin{array}{l}\text { Sodium } \leq 330 \\
\mathrm{mg} / 100 \mathrm{~g}\end{array}$} & \multicolumn{2}{|c|}{$\mathrm{SAFA} \leq 1,1 \mathrm{~g} / 100 \mathrm{~g}$} & \multicolumn{2}{|c|}{$\begin{array}{l}\text { Energy } \leq 100 \\
\mathrm{kcal} / 100 \mathrm{~g}\end{array}$} & & & & & \multicolumn{2}{|c|}{ Sodium, SAFA \& Energy } \\
\hline & A & 89 & A & 100 & A & 100 & & & & & $\mathrm{~A}$ & 89 \\
\hline & B & 91 & $\mathrm{~B}$ & 96 & $\mathrm{~B}$ & 99 & & & & & $\mathrm{~B}$ & 86 \\
\hline & $\mathrm{C}$ & 42 & $\mathrm{C}$ & 92 & $\mathrm{C}$ & 99 & & & & & $\mathrm{C}$ & 37 \\
\hline \multirow{5}{*}{$\begin{array}{l}\text { Meal } \\
\text { sauces } \\
(\mathrm{N}=190)\end{array}$} & $\begin{array}{l}\text { So } \\
\mathrm{mg}\end{array}$ & & \multicolumn{2}{|c|}{$\mathrm{SAFA} \leq 1,1 \mathrm{~g} / 100 \mathrm{~g}$} & \multicolumn{2}{|c|}{$\begin{array}{l}\text { Energy } \leq 100 \\
\mathrm{kcal} / 100 \mathrm{~g}\end{array}$} & & & & & \multicolumn{2}{|c|}{ Sodium, SAFA \& Energy } \\
\hline & A & 100 & A & 97 & A & 100 & & & & & A & 97 \\
\hline & B & 69 & B & 75 & $\mathrm{~B}$ & 100 & & & & & $\mathrm{~B}$ & 44 \\
\hline & $\mathrm{C}$ & 57 & $\mathrm{C}$ & 35 & $\mathrm{C}$ & 84 & & & & & $\mathrm{C}$ & 15 \\
\hline & $\mathrm{D}$ & 48 & $\mathrm{D}$ & 0 & $\mathrm{D}$ & 28 & & & & & D & 0 \\
\hline
\end{tabular}

Product criteria for sodium (blue), SAFA (yellow), energy (orange) and fibre (green) per product group are given, as well as the combination of all criteria per product group (grey). Empty cells indicate that the product criterium does not apply to the product group in question. $\mathrm{N}$, number of products.

*per portion

All products within the product group Cheese contained on average 0,5 grams of salt/portion, which is $8,9 \%$ of the ADI. Products with healthy score $\mathrm{A} / \mathrm{B}(\mathrm{N}=11)$ contained on average 0,2 grams of salt/portion $(3,5 \%$ of $\mathrm{ADI})$, whereas products with unhealthy score $\mathrm{D} / \mathrm{E}(\mathrm{N}=1328)$ contained on average 0,5 grams of salt/portion $(9,1 \%$ of ADI). All products within the product group Ready meals contained on average 3,4 grams of salt/portion, which is $56 \%$ of the ADI. Products with healthy score $\mathrm{A} / \mathrm{B}(\mathrm{N}=221)$ contained on average 2,9 grams of salt/portion ( $48 \%$ of $\mathrm{ADI})$, whereas products with unhealthy score $\mathrm{D} / \mathrm{E}(\mathrm{N}=41)$ contained on average 4,6 grams of salt/portion ( $77 \%$ of ADI). All products within the product group Soups contained on average 1,9 grams of salt/portion (32\% of ADI) and 1,4 grams of fibre/portion (4,6\% of RDA). Products with healthy score A/B $(\mathrm{N}=183)$ contained on average 1,8 grams of salt/portion ( $30 \%$ of $\mathrm{ADI})$ and 2,3 grams of fibre/portion (7,7\% of RDA). Moreover, all products within the product group Meal sauces contained on average 0,9 grams of salt/portion ( $15 \%$ of ADI), and 0,5 grams of fibre/portion (1,8\% of RDA). Products with healthy score $\mathrm{A} / \mathrm{B}(\mathrm{N}=51)$ contained on average 1,1 grams of salt/portion (18\% of ADI) and 1,2 grams of fibre/portion $(4,1 \%$ of RDA), whereas products with unhealthy score $\mathrm{D}(\mathrm{N}=29)$ contained on average 1 gram of salt/portion (16\% of ADI) and 0,1 grams of fibre/portion $(0,3 \%$ of RDA).

\subsection{Correlations Between Nutri-Score and Health Influencing Nutrients}

Results of single regression analysis are shown in Table 3. Most correlations between Nutri-Score and health influencing nutrients are of a low-moderate type, except for some high correlations in the product groups Ready meals 
and Meal sauces.

Table 3. Spearman's correlation coefficients (r) for the correlation between Nutri-Score and nutrients, per product group.

\begin{tabular}{llllllll}
\hline & Sugar & SAFA & Sodium & Energy & FVL & Fibre & Protein \\
\hline Cheese & $0,12^{*}$ & $-0,45^{*}$ & $-0,49^{*}$ & $-0,54^{*}$ & $0,16^{*}$ & $0,09^{*}$ & $-0,22^{*}$ \\
Ready meals & 0,00 & $-0,71^{*}$ & $-0,75^{*}$ & $-0,70^{*}$ & $0,51^{*}$ & $0,52^{*}$ & $-0,56^{*}$ \\
Soups & $0,31^{*}$ & $0,15^{*}$ & $-0,50^{*}$ & $0,48^{*}$ & $0,51^{*}$ & $0,63^{*}$ & $0,63^{*}$ \\
Meal sauces & $0,33^{*}$ & $-0,61^{*}$ & $-0,44^{*}$ & $-0,47^{*}$ & $0,85^{*}$ & $0,58^{*}$ & 0,07 \\
\hline
\end{tabular}

Simple linear regression was performed to determine the p-values. * indicates a significant correlation between Nutri-Score and nutrients (p-value $\leq 0,05)$. Negative $r$ represents a negative correlation, positive $r$ represents a positive correlation. FVL, Fruit, Vegetables and Legumes.

Multiple regression analysis was carried out for the product groups Cheese (Nutri-Score vs. SAFA + sodium together), Ready meals (Nutri-Score vs. SAFA + sodium together) and Meal sauces (Nutri-Score vs. sugar + sodium together). Among the product group Cheese, there was a significant moderate correlation between Nutri-Score and SAFA + sodium together $(\mathrm{R}=0,64, \mathrm{p} \leq 0,05)$. Among the product group Ready meals, there was a significant high correlation between Nutri-Score and SAFA + sodium together $(\mathrm{R}=0,84, \mathrm{p} \leq 0,05)$. Moreover, among the product group Meal sauces, there was a significant moderate correlation between Nutri-Score and sugar + sodium together $(\mathrm{R}=0,61, \mathrm{p} \leq 0,05)$.

\section{Discussion}

The aim of this study was to investigate the applicability of Nutri-Score in the Netherlands, by comparing Nutri-Score with Dutch dietary guidelines and Dutch Choices criteria in different product groups. In general, it was found that there is an uneven distribution of the products among the different Nutri-Scores, Nutri-Scores of a great amount of products are not in line with Dutch Choices criteria and - dietary guidelines and there is no high correlation between NutriScore and health influencing nutrients in most product groups.

This study shows that the distribution of the products among the different Nutri-Scores (A-E) is not well-balanced. Among the product group Cheese, the distinctiveness of Nutri-Score was low. The vast majority of products within this product group scored an unhealthy $\mathrm{D}$ and only a small amount scored a healthy A/B. This implies that, according to Nutri-Score, most cheeses were unhealthy. The fact that most products scored a D may be explained by the absence of healthy points from fibre and FVL and the presence of points from unhealthy nutrients such as SAFA and sodium. The amount of healthy points from protein was on average high, although this still seemed to be overshadowed by the amount of unhealthy points. This can be explained by the fact that, according to Nutri-Score, products that are high in sugar, salt, saturated fat and energy are not generally classified as 'healthier', despite the high content in proteins [25]. The fact that the French get their daily protein intake mainly from protein food groups other than cheese (such as milk, yoghurt and bread), might explain why cheese - although high in protein and calcium - ends up in the lower nutritional product categories [26]. The fact that most cheeses end up with a low score might be confusing to Dutch consumers, as the consumption of cheese has been a life-long tradition in the Netherlands and a source of important nutrients such as calcium and vitamin B12 [5, 27].

Among the product group Ready meals, the distinctiveness of Nutri-Score was also quite low. More than half of the products scored a healthy $\mathrm{A} / \mathrm{B}$, whereas only a small amount scored an unhealthy $\mathrm{D} / \mathrm{E}$, of which only very few products scored an E. The distribution of the score in Ready meals was more balanced than in the other product groups. An explanation for this might be that as Nutri-Score is based on nutritional guidelines for a total diet, the algorithm attributes many points to FVL. Ready meals reflect (part of) a total diet and thus in general get a healthy score. It may be possible that unhealthy nutrients in a meal are neutralised by the presence of other, more healthy nutrients. However, despite the average high amount of healthy points from protein and the low amount of unhealthy points from sugar, some products still scored a D/E. Again, this could be explained by the fact that products with high protein content are not generally classified by Nutri-Score as 'healthier' [25]. Important to note is that Nutri-Score is calculated by using the nutrient content per 100 grams or 100 millilitres of a food product, which means that portion size, or the total meal consumed, is not taken into consideration in the score calculation. And as the sizes of the ready meals were all $\geq$ 350 grams, this could lead to underestimation of the final score. The fact that more than half of the ready meals get a healthy score could still be misleading to the consumer, as it has been shown that ready meals in general do not have a healthful nutritional profile $[20,28]$.

Among the product group Soups, the distinctiveness of Nutri-Score was lowest compared to all other product groups because of the score range that had shifted from A-E towards A-C. It seemed that unhealthy nutrients did not largely contribute to the final score because of the absence of unhealthy points from sugar and SAFA, which may be an explanation for scoring a $\mathrm{C}$ at the lowest. Normally, a product that scores a $\mathrm{C}$ is according to Nutri-Score of moderate nutritional quality, as the scores ranges from $\mathrm{A}$ best nutritional quality (or healthy) to E worst nutritional quality (or unhealthy). However, consumers could interpret products with a $\mathrm{C}$ as relatively healthy and thereby consider these products a good choice, while in fact $\mathrm{C}$ is the unhealthiest choice within this product group.

Furthermore, among the product group Meal sauces, the 
distinctiveness of Nutri-Score was low too because of the score range that had shifted from A-E towards A-D. According to the French dietary guidelines, it is advised to limit the total consumption of fat to maintain a healthy diet [29]. So, the fact that no products scored an unhealthy E, could be explained by the absence of high amounts of unhealthy points from saturated fat. Given the fact that $\mathrm{C}$ prevails over the other scores, could mislead consumers in making a well-informed decision on what 'the healthiest choice' is within this product group at the point of purchase.

Next, it was found that Nutri-Scores of a great amount of products are not in line with the Dutch Choices criteria. In other words, healthy products did not always correspond to a healthy score $(\mathrm{A} / \mathrm{B})$, same for unhealthy products and an unhealthy score $(D / E)$.

Among the product group Cheese, the products that scored an $\mathrm{A} / \mathrm{B}$ met all criteria, meaning that the healthy scores indeed corresponded to a healthy product. Also, a large amount of the products that scored a $\mathrm{C}$ met all criteria but did not get the expected healthy A/B-score. The same goes for some of the D-products. In addition, it was surprising that the vast majority of the D-products did meet the sodium criterium, but still scored no better than an unhealthy D. An explanation for the mismatch between product criteria and - score is that, according to Nutri-Score cheese products that meet the sodium- and/or the SAFAcriterium can still score a maximum of 9 and 10 unhealthy points, respectively [12].

Among the product group Ready meals, only a small amount of the A/B-products met all criteria, meaning that most of the healthy scores did not correspond to a healthy product. In contrast, none of the D/E-products met all criteria, indicating that the unhealthy products did correspond to an unhealthy score. Looking at the individual criteria, only a small amount of the products met the sodium criterium, of which most of them scored an A. However, this meant that some A-products did not meet the sodium criterium and thus contained $>240 \mathrm{mg}$ sodium $/ 100$ g, although one would expect that products with an A ('the healthiest option') would meet the criterium near $100 \%$. Moreover, only a small amount of the products within this product group met the fibre $\# 2$ criterium $(\geq 150 \mathrm{~g}$ vegetables/portion), of which almost two thirds were scored with an A. This meant not only that most of these products did not reach the recommended amount of vegetables for a healthy ready meal, but also that more than one third of the A-products did not reach this criterium. In addition, one third of the products that scored an E did meet the fibre \#1 criterium. An explanation for this is that, according to Nutri-Score, products that contain $\geq 1,2 \mathrm{~g}$ fibre/100 $\mathrm{g}$ (the fibre \#1 criterium) only score a maximum of 5 healthy points. Nevertheless, it is difficult to draw this conclusion since it is based on a relatively small sample of products $(\mathrm{N}=3)$ scoring an $\mathrm{E}$ within this product group.

Among the product group Soups, not all A-products, nor B-products, met all criteria, meaning that not all of the healthy scores corresponded to a healthy product. The small amount of A-products that did not meet all criteria was due to these products not meeting the sodium criterium. Most of the products that scored a $\mathrm{C}$ met the SAFA- and energy criterium, which is quite a healthy score for a product of only moderate nutritional quality.

Among the product group Meal sauces, nearly all of the Aproducts and about half of the B-products met all criteria, meaning here too that not all healthy scores corresponded to a healthy product.

In addition, it was examined to what extent products - on average and per score-category - would contribute to the reference daily intake of a certain nutrient. Here, it was concluded that Nutri-Scores of a great amount of products are not in line with the current Dutch dietary guidelines.

All products within the product group Cheese contained on average $0,5 \mathrm{~g}$ salt/portion, $(8,9 \%$ of the ADI). This is a low percentage. However, taking into consideration the average daily bread consumption of Dutch adults, which is 3,5 slices of bread/day (and for males even 4,5), this might result in higher intakes as percentage of the ADI $[17,21]$. If a Dutch adult would consume two slices bread with each a slice of cheese on a daily basis, the ADI of salt would increase up to almost $20 \%$, excluding the amount of salt from the bread.

All products within the product group Ready meals contained on average $3,4 \mathrm{~g}$ salt/portion (56\% of the ADI). An average ready meal $(700 \mathrm{kcal})$ is $35 \%$ of the reference daily energy intake [23, 30, 31]. If this meal would contain on average already more than $50 \%$ of the ADI of salt, however, chances are high that an adult who consumes $2000 \mathrm{kcal} /$ day will end up consuming more than the ADI of salt. Products that scored a healthy $\mathrm{A} / \mathrm{B}$ contained on average 2,9 $\mathrm{g}$ salt/portion, which is $48 \%$ of the ADI. This again shows that products with a healthy $\mathrm{A} / \mathrm{B}$-score are not always as healthy as they might seem. Besides, an A/B-product that is high in salt could be misleading to consumers, assuming they have chosen the healthiest option. The actual consumption of such a product could even pose a threat to their overall health, there being an association between ready meal consumption and overweight [32].

The products that scored an A/B within the product group Soups contained on average 1,8 g salt/portion (30\% of the ADI), which is a high amount of salt for a product with a healthy score. Furthermore, soup is often consumed as a starter. And although it has been shown that soup as a starter leads to overall less intake of total kilocalories during the entire meal (starter + main course), this does not account for the intake of total salt. On the contrary, soups that are high in salt have shown to increase the consumption of salt during a second course $[33,34,35]$. Although the $\%$ fibre of the RDA in A- and B-products was greater than in C-products, it still is only $7,7 \%$ of the ADI. Soup is a non-basic food product that does not make a substantial contribution to the intake of this essential nutrient [8]. This does mean that the vast majority of fibre, more than $90 \%$, must come from different (basic) food sources to reach the RDA of 30-40g fibre/day [23].

All products within the product group Meal sauces contained on average $0,9 \mathrm{~g}$ salt/portion $(15 \%$ of the ADI). 
Thereby, meal sauces not largely contribute to the ADI of salt. However, the fact that A- and B-products contributed more to the ADI of salt than D-products ( $18 \%$ and $16 \%$, resp.) is rather confusing, because products with a healthy $\mathrm{A} / \mathrm{B}$ are expected to contain less salt than products with an unhealthy D. Similar to Soups, the \% fibre of the RDA in A- and Bproducts was greater than in the other products, although it still was no higher than $4,1 \%$ of the RDA. Meal sauces are also regarded as non-basic food products and the vast majority of fibre must come from additional (basic) food sources to reach the RDA [8].

In this study, it was found that there is no high correlation between Nutri-Score and health influencing nutrients in most product groups. In general, it was expected that there would be a high negative correlation between Nutri-Score and unhealthy nutrients (unhealthy nutrients increase when score decreases to a D or E), and a high positive correlation between Nutri-Score and healthy nutrients (healthy nutrients increase when score increases to an A or B). This was not the case for the product group Cheese. In this product group, there was a low negative correlation between Nutri-Score and unhealthy nutrients SAFA and - sodium. This may be explained by the large amount of cheese products that scored a D, and thereby largely contributing to the high presence of unhealthy nutrients in this product group. Multiple correlations between Nutri-Score and SAFA + sodium together were significantly higher than the correlations between Nutri-Score and the individual nutrients, but still of moderate degree. Furthermore, there was no significant correlation between Nutri-Score and sugar, - FVL, fibre and - protein, because sugar, FVL and fibre are generally not present in cheese products and the amount of protein is on average high [36, 37].

In the product group Ready meals, there was a significant high negative correlation between Nutri-Score and SAFA, sodium, and -energy, as well as between Nutri-Score and SAFA + sodium together. Similar to Cheese, there was no significant correlation between Nutri-Score and sugar, which can be explained by the average low amount of sugar present in these ready meals. As mentioned in the beginning of this paragraph, it would be expected that as the score decreases, the amount of a healthy nutrient also decreases. Indeed, a significant positive correlation was found between NutriScore and FVL and - fibre, but only of moderate degree. A negative moderate correlation between Nutri-Score and protein was found, indicating the increase of protein - instead of the expected decrease - as the score decreased.

In the product group Soups, the correlation between NutriScore and sugar and - SAFA was low, as the amount of nutrients stayed constant as the score increased. In addition, significant correlations were found between Nutri-Score and sodium, -FVL, -fibre, and -protein, although all of moderate degree.

In the product group Meal sauces, there was a significant low negative correlation between Nutri-Score and sodium. However, a high(er) correlation would be expected given the fact that sauces are often high in salt [6, 31]. Furthermore, there was a significant low positive correlation between
Nutri-Score and sugar. The low positive correlation can be explained by the fact that sugar was on average low in these products. Multiple correlations between Nutri-Score and sodium + sugar together were low too. Moreover, a significant negative correlation was found between NutriScore and SAFA, although once more of moderate degree. And despite a significant high positive correlation was found between Nutri-Score and FVL, no high positive correlations were found between Nutri-Score and the remaining healthy nutrients fibre and - protein. This can be explained by the fact that fibre and protein was on average low in these products. From the above it can be concluded that no strong association was found between Nutri-Score and nutrient(s) within the four product groups, except for some nutrients within Ready meals and Meal sauces. It is difficult to conclude whether the high correlations found between NutriScore and nutrients were also of causal nature.

Furthermore, there were some remarks and limitations regarding Nutri-Score and its compliance with the Dutch Choices criteria and - dietary guidelines. First, Nutri-Score is based on nutritional guidelines and not on product groupspecific criteria, which resulted in the uneven distribution of Nutri-Score in the different product groups. In addition, these nutritional guidelines are of French origin, making it difficult to compare these guidelines to Dutch dietary guidelines. Second, Nutri-Score is calculated by using the nutrient content per 100 grams or 100 millilitres of a food product. This means that portion size - in what amount a product is consumed- is not taking into consideration in the score calculation. A score based on $100 \mathrm{~g} / 100 \mathrm{ml}$ of a product instead of portion size could therefore result in systemic underestimation of the final score, especially in product groups were portion size matters, such as Ready meals. Third, the unhealthy points seem often to overshadow the healthy points, even if the presence of healthy points is on average quite high, as demonstrated by the scores for Cheese. This could be explained by the fact that a maximum of 10 points can be allocated to unhealthy nutrients, against a maximum of only 5 points to healthy nutrients. It is a systemic choice by the Nutri-Score organisation to assign more points to nutrients that have a negative influence on health compared to health promoting nutrients. Another choice of the organisation in the algorithm is, that compensation is possible within Nutri-Score. In other words, unhealthy nutrients such as sugar or salt could be added to vegetables, without deterioration of the score. This might explain the non-conformity with the Dutch Choices criteria and dietary guidelines. Last, lack of selectivity of Nutri-Score within product groups and the lack of selecting healthier products within a product group might be explained by the following. Part of Nutri-Score's purpose, as formulated by the founders, is 'to orient consumers towards healthier food choices at the point of purchase' [13]. In light of this, it would make more sense to introduce the score on products which are easy to distinguish in nutritional value (such as ready meals), than products which are more difficult to distinguish (such as cheeses). Again, this might mean the use of product group- 
specific criteria instead of a generic algorithm for all products, to be able to properly distinguish products within their own product group.

\section{Conclusion}

To conclude, for the studied product groups Nutri-Score is not properly selecting healthier products and its scores are not very consistent with Dutch dietary guidelines. The current study shows that for the product groups Cheese, Ready meals, Soups and Meal sauces, there is an uneven distribution of the products among the different Nutri-Scores, Nutri-Scores of a great amount of products are not in line with Dutch Choices criteria and - dietary guidelines and there is no high correlation between Nutri-Score and health influencing nutrients in most product groups. If the purpose of Nutri-Score is to orient consumers towards healthier food choices, then the foods that are displayed as healthy should not contradict to Dutch dietary guidelines - and patterns. Now that the Dutch Government has decided to implement Nutri-Score as the new FOP-label, it is advised to look into the possibilities to adapt the score to product group-specific criteria in line with (Dutch) guidelines. This might become a challenge on not only scientific but also regulatory level, since Nutri-Score's usage regulation lies with the French national public health agency [38].

\section{Acknowledgements}

The authors would like to thank Boy Persoon for his help in data collection. In addition, the authors would like to thank Hoogvliet for sharing nutritional product data of several product groups.

\section{References}

[1] Mcintyre, D. WHO global coordination mechanism on the prevention and control of noncommunicable diseases Working Group on how to realize governments' commitment to provide financing for NCDs Policy Brief Domestic financing for NCDs. $\quad$ http://www.who.int/nmh/ncd-coordinationmechanism/en/. (2015).

[2] WHO. Global Strategy on Diet, Physical Activity and Health. (2004).

[3] Rijksoverheid. Nationaal Preventieakkoord. https://www.rijksoverheid.nl/binaries/rijksoverheid/documente n/convenanten/2018/11/23/nationaal-

preventieakkoord/nationaal-preventieakkoord.pdf (2018).

[4] Gezondheidsraad. Advies Richtlijnen Goede Voeding 2015. (2015).

[5] Voedingscentrum. Gezond en duurzaam met de Schijf van Vijf. https://www.voedingscentrum.nl/nl/gezond-eten-met-deschijf-van-vijf.aspx (2019).

[6] Voedingscentrum. Wat staat er niet in de Schijf van Vijf? https://www.voedingscentrum.nl/nl/gezond-eten-met-deschijf-van-vijf/omgaan-met-producten-buiten-de-schijf-van- vijf.aspx (2019).

[7] NOS. Veel aanbiedingen in supermarkten zijn ongezond. https://nos.nl/artikel/2290423-veel-aanbiedingen-insupermarkten-zijn-ongezond.html (2019).

[8] Stichting Ik Kies Bewust. Productcriteria. (2015).

[9] Jansen, L. \& Roodenburg, A. The use of food composition data in the Choices International Programme. Elsevier 193, 196-202 (2016).

[10] Stichting Ik Kies Bewust. Het Vinkje verdwijnt van de verpakking. https://www.hetvinkje.nl/nieuws/actueel/stichting-ik-kiesbewust-wordt-opgeheven/ (2018).

[11] Van Der Bend, D. L. M. \& Lissner, L. Differences and Similarities between Front-of-Pack Nutrition Labels in Europe: A Comparison of Functional and Visual Aspects. Nutrients 11, 1-16 (2019).

[12] Julia, C. \& Hercberg, S. Development of a new front-of-pack nutrition label in France: the five-colour Nutri-Score. Public Heal. Panor. 3, 712-725 (2017).

[13] Julia, C. \& Hercberg, S. Nutri-Score: evidence of the effective-ness of the French front-of-pack nutrition label. Ernahrungs Umschau 64, 181-187 (2017).

[14] Food Navigator. NutriScore under fire: Debate rages over nutritional labelling in Germany. https://www.foodnavigator.com/Article/2019/04/26/NutriScor e-under-fire-Debate-rages-over-nutritional-labelling-inGermany (2019).

[15] Eichorn, L. Nutri-Score: Die Lebensmittel-Ampel kommt. https://www.tagesschau.de/inland/nutriscore-101.html (2019).

[16] RIVM. Nutri-Score wordt na aanpassing het voedselkeuzelogo voor Nederland. https://www.rijksoverheid.nl/actueel/nieuws/2019/11/28/nutriscore-wordt-na-aanpassing-het-voedselkeuzelogo-voornederland (2019).

[17] RIVM. Voedselconsumptiepeiling. https://www.wateetnederland.nl/ (2016).

[18] Rabobank. Supermarkten: ontwikkeling consumentengedrag. https://www.rabobank.nl/bedrijven/cijfers-entrends/food/supermarkten/ (2019).

[19] Foodmagazine. Assortiment: trends in verse maaltijden. https://www.foodmagazine.nl/assortiment/artikel/2018/07/asso rtiment-trends-in-verse-maaltijden-1014530?vakmedianetapprovecookies $=1 \&$ ga $=2.101415298 .229506958 .1563269425$ 2006139651.1559891908 (2018).

[20] Voedingscentrum. Alles over gezond, duurzaam en veilig eten. https://www.voedingscentrum.nl/nl.aspx (2019).

[21] RIVM. Portie-online. https://portie-online.rivm.nl/ (2018).

[22] Veelgestelde vragen over de Nutri-Score | FOD Volksgezondheid. https://www.health.belgium.be/nl/veelgestelde-vragen-overde-nutri-score.

[23] Voedingscentrum. Referentie-inname. https://www.voedingscentrum.nl/encyclopedie/referentieinname.aspx. 
[24] Stichting Ik Kies Bewust. Voedingsstoffen. https://www.hetvinkje.nl/gezonder-leven/voedingsstoffen/ (2019).

[25] Julia, C. et al. Discriminating nutritional quality of foods using the 5-Color nutrition label in the French food market: consistency with nutritional recommendations. Nutr. J. (2015) doi: 10.1186/s12937-015-0090-4.

[26] de Gavelle, E. et al. Self-declared attitudes and beliefs regarding protein sources are a good prediction of the degree of transition to a low-meat diet in France. Appetite 142, (2019).

[27] ZuivelNL. Nederland zuivelland Moderne sector. www.zuivelnl.org (2015).

[28] Remnant, J. \& Adams, J. The nutritional content and cost of supermarket ready-meals. Cross-sectional analysis. Appetite 92, 36-42 (2015).

[29] FAO. Food-based dietary guidelines - France. http://www.fao.org/nutrition/education/food-based-dietaryguidelines/regions/countries/france/fr/.

[30] RIVM. Voedingsstatusonderzoek. https://www.rivm.nl/voedselconsumptiepeiling/voedingsstatus onderzoek.

[31] Rijksoverheid. Akkoord Verbetering Productsamenstelling. https://www.rijksoverheid.nl/documenten/convenanten/2014/0 1/23/akkoord-verbetering-productsamenstelling-zoutverzadigd-vet-suiker (2014).

[32] Van Der Horst, K., Brunner, T. A. \& Siegrist, M. Ready-meal consumption: Associations with weight status and cooking skills. Public Health Nutr. 14, 239-245 (2011).

[33] Grit, C., Crielaard, H. \& Tiesinga, I. Ketenbrede afspraak voor soepen en bouillons. (2014).

[34] Flood, J. E. \& Rolls, B. J. Soup preloads in a variety of forms reduce meal energy intake. Appetite 49, 626-634 (2007).

[35] Bolhuis, D. P., Lakemond, C. M. M., de Wijk, R. A., Luning, P. A. \& de Graaf, C. Effect of salt intensity in soup on ad libitum intake and on subsequent food choice. Appetite 58, 48-55 (2012).

[36] O'Brien, N. M. \& O'Connor, T. P. Nutritional aspects of cheese: Is cheese good for your teeth? in Cheese Problems Solved 155-156 (Elsevier Ltd., 2007).

[37] RIVM. Nederlands Voedingsstoffenbestand (NEVO). https://nevo-online.rivm.nl/.

[38] Santé publique France. USAGE REGULATION FOR THE "NUTRI-SCORE"

file://C:/Users/Charlotte/Downloads/Nutri-

LOGO. score_reglement_usage_EN_041019(3).pdf(2019). 